\title{
The Physicochemical, Microbiology, and Sensory Characteristics of Kefir Goat Milk with Different Levels of Kefir Grain
}

\author{
Sulmiyati ${ }^{\mathrm{a}, *}$, N.S. Said ${ }^{\mathrm{a}}$, D.U. Fahrodi ${ }^{\mathrm{a}}$, R. Malaka ${ }^{\mathrm{b}}$, \& F. Maruddin ${ }^{\mathrm{b}}$ \\ ${ }^{a}$ Faculty of Animal Husbandry and Fisheries, Universitas Sulawesi Barat \\ ${ }^{b}$ Faculty of Animal Science, Hasanuddin University \\ Jalan Prof. Dr. Baharuddin Lopa, SH. Talumung, Majene 91413, Sulawesi Barat, Indonesia \\ *Corresponding author: sulmiyati@unsulbar.ac.id \\ (Received 08-01-2019; Revised 29-03-2019; Accepted 03-05-2019)
}

\begin{abstract}
Kefir is a fermented milk product. The kefir grain starter consists of lactic acid bacteria and yeast that produce lactic acid and alcohol. The quality of kefir is strongly influenced by the type of milk used, the amount of kefir grain, kefir grain microorganisms, and the incubation period. The characteristics of goat-milk kefir with the addition of different amounts of kefir grain were studied by measuring $\mathrm{pH}$ value, ethanol content, and percentage of lactic acid. The experimental design was a completely randomized design (RCD) with three treatments and five replications. The treatments were performed by using different amounts of kefir grains i.e., $2 \%, 4 \%$, and $6 \%$. Goat-milk kefir was pasteurized at $105^{\circ} \mathrm{C}$ for 5 minutes, cooled at room temperature $\left(37^{\circ} \mathrm{C}\right)$, and then kefir grain was added at different levels and incubated for 12 hours. The results showed that the amounts of kefir grain had a significant effect $(p<0.05)$ on $\mathrm{pH}$ value, the percentage of lactic acid, and ethanol content of goat-milk kefir produced. The higher dose of kefir grain had an influence on physicochemical characteristics, microbiology, and sensory of goat-milk kefir. The optimal characteristics of goat-milk kefir were $2 \%$ kefir grain with a $\mathrm{pH}$ value of 5.40 , lactic acid content of $0.14 \%$, and ethanol content of $0.69 \%$. The weight gain of kefir grain was $7.21 \%$ and the total of lactic acid bacteria was $1.64 \times 10^{7} \mathrm{CFU} / \mathrm{mL}$. Sensory quality had a white color, kefir scent, a non-acid taste, and like preference. It is concluded that the best goat-milk kefir can be produced by the addition of $2 \%$ kefir grain based on physicochemical, microbiological, and sensory characteristics.
\end{abstract}

Keywords: physicochemical characteristic; kefir goat; kefir grain

\section{INTRODUCTION}

Kefir is a fermented product other than yoghurt that has health benefits. Kefir is a dairy product produced by fermentation of various animal milk (i.e., goat and cow) by adding kefir grain. Kefir grain has yellow color with sizes varying from $1-6 \mathrm{~mm}$ in diameter (Yilmaz-Ersan et al., 2016).

The quality of kefir is strongly influenced by the type of milk used, the dose of kefir grain, the type of lactic acid bacteria, the yeast, and the incubation time. Kefir is also known with various name i.e., kefyr, kephir, kefer, kiaphur knapon, kepi or kippi (Arslan, 2015). Chen et al. (2005) report that the acid taste of kefir is caused by the lactic acid, some effervescence due to carbon dioxide, and alcohol concentration from the action of yeast cell in the grains. Kefir contains a complex mixture of Lactic Acid Bacteria, acetic bacteria, and yeast. Gao \& Li (2016) reported microflora species in kefir and kefir grains were Lactic Acid Bacteria (Lactobacilli, Lactococci, Streptococci), Acetic Bacteria and yeast (Candida sp., Kazachstania sp., Kluyveromyces sp., Saccaromyces sp., Torulosis Sp., Zygosaccharomyces sp.). Several types of bacteria were identified which were found in kefir grain i.e., Lb. Kefiri (Leite et al., 2013); Lb. casei (Wang et al., 2008; Gulitz et al., 2011), Lb. fermentum (Wang et al., 2008); Lb. acidophilus (Taş et al., 2012); Lactococcus lactis (Leite et al., 2013); Streptococcus thermophilus (Taş et al., 2012), and yeast ie., Candida albicans (Wang et al., 2008); Saccaromyces cerevisiae (Garofalo et al., 2015); Kluyeromyces marxianus (Vardjan et al., 2013; Zhou et al., 2013), and Pichia caribbica (Miguel et al., 2011).

According to Lengkey et al. (2013), the optimal kefir had $10 \%$ of kefir grain, 3.95 of $\mathrm{pH}$ value, and 3,190 grains of weight gain. Yusriyah \& Agustini (2014) demonstrated the $\mathrm{pH}$ value of cow's milk kefir with the addition of 3\% kefir grain was 5.22 after 24 hours of incubation time. Setyawardani et al. (2014) demonstrated that $1 \%$ of kefir grain concentrate, 4.5 of $\mathrm{pH}$ in a controlled fermentation, and $0.23 \%$ of alcohol could produce a good kefir. Purnomo \& Muslimin (2012) found the best kefir with an addition of $7 \%$ kefir grain with 24 hours incubation, producing a $\mathrm{pH}$ of 4.63 and $0.73 \%$ lactic acid percentage, $0.92 \%$ ethanol, and the best goat-milk kefir with the addition of $7 \%$ kefir grain for 24 hours incubation time. The characteristics of kefir depend on the duration of fermentation (Lengkey \& Balia, 2014), the medium used (Lengkey, 2002), fermentation 
temperature (Setyawardani et al., 2014), and the ratio of kefir grain with milk (Agustina et al., 2013); (Lengkey et al., 2013). Sulmiyati et al. $\left(2018^{\mathrm{b}}\right)$ reported the type of bacteria, temperature, duration of fermentation, and the type of milk were used as the parameters to characterize kefir.

The characterization of kefir with different levels of kefir grain and time of incubation is limited. Therefore, it is urgently needed to measure and collect these informations. The experiment was designed to measure the characteristics of goat-milk kefir produced with the addition of different levels of kefir grain based on $\mathrm{pH}$ value, ethanol content, lactic acid percentage, weight gain of kefir grains, total lactic acid bacteria, and sensory characteristics of color, smell, taste, and preference.

\section{MATERIALS AND METHODS}

\section{Kefir Grain}

The goat milk was obtained from Majene, West Sulawesi. Kefir grains were obtained from commercial kefir grains, the lactic acid bacteria identified were Lactococcus cremoris, Streptococcus cremoris, Lactobacillus plantarum, and the yeast was Saccharomyces cerevisiae (Sulmiyati et al., 2018 a). In the laboratory, they were propagated at $37^{\circ} \mathrm{C}$ for 24 hours.

\section{Manufacture of Goat-Milk Kefir}

Goat milk was produced by heating at $105^{\circ} \mathrm{C}$ for 5 minutes (steam sterilizer, Tomy S-500), then cooled to a room temperature at $37^{\circ} \mathrm{C}$ (Sulmiyati et al., 2018 ${ }^{\mathrm{b}}$ ). Then, kefir grain was added at the levels of $2 \%, 4 \%$, and $6 \%$, and incubated for 12 hours at $37^{\circ} \mathrm{C}$ (incucell). The experiments were repeated with five replications.

\section{Measurements of Physicochemical Characteristics of Kefir}

pH of kefir. The $\mathrm{pH}$ value of kefir produced was determined by using a $\mathrm{pH}$ meter (HANNA). The $\mathrm{pH}$ meter was calibrated using $\mathrm{pH} \mathrm{7,} \mathrm{pH} 4$, and $\mathrm{pH} 10$. The $\mathrm{pH}$ meter was dipped into $5 \mathrm{~mL}$ beaker glass (pyrex) containing $3 \mathrm{ml}$ of kefir sample.

Lactic acid percentage. The percentage of lactic acid was measured by following the method of Purnomo \& Muslimin (2012). The acid level was determined by titration using $0.1 \mathrm{~N} \mathrm{NaOH}$ for $5 \mathrm{~mL}$ of kefir which was dropped 2 drops of PP Indicator (Phenolphthalein Indicator) until the kefir sample was pink. Calculation of acid levels was performed as follow:

Percentage of lactic acid $=(\mathrm{mL} \mathrm{NaOH} \times 0.009) \times($ weight of milk (g) $)^{-1} \times 100 \%$

The percentage of ethanol. The ethanol content of goat-milk kefir was determined through a method used by Yulianti (2014) i.e., $10 \mathrm{~g}$ of kefir was placed into an Erlenmeyer glass (pyrex), dripped 2 drops of phenolphthalein indicator, and $50 \mathrm{~mL}$ of distilled water. The ethanol percentage was determined by titrating with $\mathrm{NaOH} 0.1 \mathrm{~N}$. The titration was terminated until the kefir sample was pink. Measurement of ethanol percentage was performed as follow:

Percentage of ethanol content $=$

(A $\times$ M $\times$ Mr) $\times(\text { Sample weight })^{-1} \times 100 \%$

where $\mathrm{A}$ is average of titration result $(\mathrm{mL}), \mathrm{M}$ is molarity of $\mathrm{NaOH}(0.1 \mathrm{~N})$, and $\mathrm{Mr}$ is relative mass of $\mathrm{C}_{2} \mathrm{H}_{5} \mathrm{OH}=$ 46.

The weight gain of kefir grain. The weight gain of kefir grains was measured by using the method of Lengkey (2002). Kefir grains were weighed (Analytical scales, Radwag PS 600 C2) as much as 2\%, 4\%, and 6\% of the volume of goat's milk. Kefir grain was added to goat's milk which was pasteurized and cooled to reach room temperature $\left(37^{\circ} \mathrm{C}\right)$. Then, the mixture was incubated for 12 hours at $37^{\circ} \mathrm{C}$. At the end of fermentation, the kefir grain was filtered and weighed (Analytical scales, Radwag PS 600 C2). The results were calculated as follow:

Weight gain of grain $=(\mathrm{F}-\mathrm{A}) \times \mathrm{A}^{-1} \times 100 \%$

where $\mathrm{F}$ is the weight of kefir grain after fermentation and $\mathrm{A}$ is the weight of kefir grain before fermentation.

The total lactic acid bacteria of goat-milk kefir. The calculation of the total lactic acid bacteria was determined by using the method of Swanson et al. (1992). The sample volume of $1 \mathrm{~mL}$ of kefir was put into $9 \mathrm{~mL}$ of sterile distilled water solution with a dilution of $10^{-1}$, $10^{-2}, 10^{-3}, 10^{-4}, 10^{-5}, 10^{-6}$ then vortexed (Schoot). The dilutions of $10^{-5}$ and $10^{-6}$ were performed with $0.1 \mathrm{~mL}$ of de Man, ROGOSA, Sharpe Agar (MRS-Agar, Merck) into a petri dish. Incubation were conducted at $37^{\circ} \mathrm{C}$ for 24 hours and the growing colonies were calculated by using colony counter (WTW, BZG 30). The calculation was determined by selecting colonies that grew from 25-250 colonies in a petri dish and included as follow:

$\begin{aligned} & \text { Colony/gram }(\mathrm{CFU} / \mathrm{mL})= \text { The number of colonies } \times(1 / \\ &\text { dilution factor })\end{aligned}$

\section{Sensory Measurement of Goat-Milk Kefir}

Sensory measurements of goat-milk kefir was determined by 20 people of trained panelists. The tests were conducted to examine the attributes of color, smell, taste, and preference for goat-milk kefir with a range of 1-5. The rating scale of the instrument can be seen in Table 1. Each sample was given a code of two-digit numbers randomly. Sensory measurements were performed by panelists.

\section{Tabulation and Analysis of Data}

The study was designed with a randomized complete design (RCD) with three levels of kefir grains (A1= $2 \%$; $\mathrm{A} 2=4 \%$; $\mathrm{A} 3=6 \%$ ) with 5 replications. The data were 
Table 1. Rating scale of sensory test

\begin{tabular}{lccccc}
\hline \multirow{2}{*}{ Sensory parameters } & \multicolumn{5}{c}{ Scale } \\
\cline { 2 - 5 } & \multicolumn{1}{c}{1} & 2 & 3 & 4 & 5 \\
\hline Color & very yellow & yellow & slightly yellow & white & very white \\
Smell & has no kefir scent & has little kefir scent & slightly kefir scent & kefir scent & has a high kefir scent \\
Taste & very acid & acid & slighltly acid & poor acid & not acid \\
Preference & very dislike & dislike & slightly like & like & very like \\
\hline
\end{tabular}

analyzed by analysis of variance (ANOVA). Then, if the effect was significant, the treatment differences were tested by the Least Significant Difference (LSD) test. The sensory testing was analyzed by using a non-parametric test of one way ANOVA.

\section{RESULTS}

\section{pH of Goat-Milk Kefir}

The $\mathrm{pH}$ of goat-milk kefir produced with different amounts of kefir grain was in the range of $4.76 \pm 0.540$ to $5.40 \pm 0.100$. The highest $\mathrm{pH}$ was $5.40 \pm 0.100$ found in the goat-milk kefir produced with the addition of $2 \%$ kefir grain and the lowest $\mathrm{pH}$ was $4.76 \pm 0.540$ and found in the goat-milk kefir produced with the addition of $6 \%$ kefir grain (Table 2). The ANOVA result showed that the $\mathrm{pH}$ values of goat-milk kefir produced were significantly $(p<0.05)$ affected by the different percentages of kefir grain.

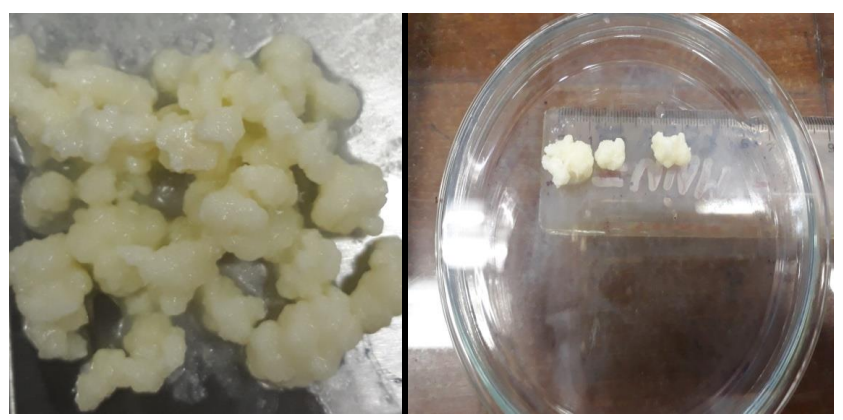

Figure 1. The morphology of kefir grain

Table 2. The mean value \pm standar deviation of physicochemical, microbiology, and sensory characteristics of goat-milk kefir at different levels of kefir grain

\begin{tabular}{|c|c|c|c|}
\hline \multirow{2}{*}{ Variables } & \multicolumn{3}{|c|}{ Level of kefir grain } \\
\hline & $2 \%$ & $4 \%$ & $6 \%$ \\
\hline $\mathrm{pH}$ value & $5.40 \pm 0.100^{a}$ & $4.96 \pm 0.114^{b}$ & $4.76 \pm 0.540^{c}$ \\
\hline $\begin{array}{l}\text { Percentage of lactic } \\
\text { acid bacteria }(\%)\end{array}$ & $0.14 \pm 0.007^{a}$ & $0.26 \pm 0.620^{\mathrm{b}}$ & $0.41 \pm 0.410^{c}$ \\
\hline Ethanol value (\%) & $0.69 \pm 0.005^{a}$ & $1.41 \pm 0.262^{\mathrm{b}}$ & $1.78 \pm 0.130^{c}$ \\
\hline $\begin{array}{l}\text { Weight gain of kefir } \\
\text { grain }(\%)\end{array}$ & $7.21 \pm 0.647^{a}$ & $7.10 \pm 0.587^{a}$ & $5.08 \pm 0.181^{b}$ \\
\hline $\begin{array}{l}\text { Total lactic acid } \\
\text { bacteria }\left(10^{7} \mathrm{CFU} / \mathrm{mL}\right)\end{array}$ & $1.64 \pm 0.008^{\mathrm{a}}$ & $1.71 \pm 0.130^{\mathrm{b}}$ & $1.76 \pm 0.015^{c}$ \\
\hline
\end{tabular}

Note: Means in the same row with different superscripts differ significantly $(\mathrm{p}<0.05)$

\section{Percentage of Lactic Acid in Goat-Milk Kefir}

The percentage of lactic acid produced was $0.14 \pm 0.007 \%-0.41 \pm 0.410 \%$. The highest percentage of lactic acid was $0.41 \pm 0.410 \%$ found in the goat-milk kefir produced with the addition of $6 \%$ kefir grains, while the lowest percentage of lactic acid was $0.14 \pm 0.007 \%$ found in the goat-milk kefir produced with the addition of $2 \%$ kefir grains (Table 2). The result of the analysis revealed that the amounts of kefir grain had a significant effect $(p<0.05)$ on the percentage of lactic acid in the goat-milk kefir.

\section{Ethanol Concentration of Goat-Milk Kefir}

In the present study, the ethanol content of goatmilk kefir produced increased in line with the increased level of kefir grain. The range of ethanol content was $0.69 \pm 0.050 \%-1.78 \pm 0.130 \%$. The highest ethanol content was found in the goat-milk kefir produced with the addition of $6 \%$ kefir grain $(1.78 \pm 0.130 \%)$ and the lowest ethanol content was found in the goat-milk kefir produced with the addition of $2 \%$ kefir grain $(0.69 \pm 0.050 \%)$ (Table 2). The result of the ANOVA showed that kefir grain level had a significant effect $(p<0.05)$ on ethanol content of goat-milk kefir produced.

\section{Total Lactic Acid Bacteria in Goat-Milk Kefir}

The range of total lactic acid bacteria of goat-milk kefir produced was $1.64 \times 10^{7}-1.76 \times 10^{7} \mathrm{CFU} / \mathrm{mL}$. The highest total lactic acid bacteria was found in goat-milk kefir produced with the addition of $6 \%$ kefir grain $\left(1.76 \times 10^{7} \pm 0.015\right) \mathrm{CFU} / \mathrm{mL}$ and the lowest total lactic acid

Table 3. The sensory characteristics of goat-milk kefir at different levels of kefir grain

\begin{tabular}{lccc}
\hline \multirow{2}{*}{$\begin{array}{c}\text { Parameter of } \\
\text { sensory }\end{array}$} & \multicolumn{3}{c}{ Level of kefir grain } \\
\cline { 2 - 4 } Color & $2 \%$ & $4 \%$ & $6 \%$ \\
& $4.00 \pm 0.001^{\mathrm{a}}$ & $4.00 \pm 0.001^{\mathrm{a}}$ & $4.00 \pm 0.001^{\mathrm{a}}$ \\
whit & white & white \\
Smell & $3.50 \pm 0.512^{\mathrm{a}}$ & $4.05 \pm 0.394^{\mathrm{b}}$ & $4.10 \pm 0.447^{\mathrm{b}}$ \\
& Kefir scent & Kefir scent & Kefir scent \\
Taste & $4.90 \pm 0.307^{\mathrm{a}}$ & $3.35 \pm 0.489^{\mathrm{b}}$ & $2.00 \pm 0.001^{\mathrm{c}}$ \\
& Not acid & Slighty acid & Acid \\
Preference & $3.50 \pm 0.760^{\mathrm{a}}$ & $4.40 \pm 0.502^{\mathrm{b}}$ & $2.70 \pm 0.656^{\mathrm{c}}$ \\
& Like & Like & Slightly like \\
\hline
\end{tabular}

Note: Means in the same row with different superscripts differ significantly $(\mathrm{p}<0.05)$. 
bacteria was found in goat-milk kefir produced with the addition of $2 \%$ kefir grain $\left(1.64 \times 10^{7} \pm 0.008\right)$ (Table 2$)$. The ANOVA results showed that the different levels of kefir grains supplementation had a significant effect $(p<0.05)$ on the total lactic acid bacteria count of goat-milk kefir produced.

\section{The Weight Gain of Kefir Grains}

The weight gain of kefir grain decreased with the increased percentage of kefir grains with the goat milk. The highest weight gain of kefir grains was $7.21 \pm 0.647 \%$ found in the mixture of $2 \%$ kefir grain with goat milk, while the lowest weight gain of kefir grains was $5.08 \pm 0.181 \%$ found in the the mixture of $6 \%$ kefir grain with goat milk. The level of kefir grain mixed with the goat milk had a significant effect $(\mathrm{P}<0.05)$ on the weight gain of the kefir grains.

\section{Evaluation of Sensory}

The result of sensory characteristic showed that the percentage of kefir grain did not have a significant effect on the color of goat-milk kefir produced. In contrast, the percentage of kefir grain had a significant effect $(p<0.05)$ on the smell, taste, and the preference of goat-milk kefir produced. The color produced by each treatment was white and the smell was the kefir scent (Table 3). The taste of goat-milk kefir produced by the addition of $2 \%$ kefir grain had a taste scale of of $4.90 \pm 0.307$ (not acid); the addition of $4 \%$ kefir grain had a taste scale of $3.35 \pm 0.489$ (slightly acid), and the addition of $6 \%$ kefir grain had a taste or flavour scale of $2.00 \pm 0.001$ (acid). The different amounts of kefir grain used produced different preference of goat-milk kefir. The used of kefir grain at the level of $2 \%$ produced goat-milk kefir with a preference scale of $3.50 \pm 0.760$ (like), the use of kefir grain at the level of $4 \%$ produced goat-milk kefir with a preference scale of $4.40 \pm 0.502$ (like), and the use of kefir grain at the level of $6 \%$ produced goat-milk kefir with a preference scale of of $2.70 \pm 0.656$ (slightly like).

\section{DISCUSSION}

\section{$\mathrm{pH}$ in Goat Milk Kefir}

The higher the percentage of kefir grain used produces goat-milk kefir with a lower $\mathrm{pH}$. This lower $\mathrm{pH}$ of goat-milk kefir produced with the higher percentage of kefir grain used is caused by the presences of lactic acid bacteria in the kefir grain. Lengkey et al. (2013) demonstrated the $\mathrm{pH}$ of kefir decreased as the level of kefir grain increased; the level of kefir grain 5\%,10\%, $15 \%, 20 \%$, and $25 \%$ produced kefir with the $\mathrm{pH}$ of 4.40 , $3.95,3.75,3.60$, and 3.50, respectively. The mechanism for decreasing $\mathrm{pH}$ is caused by the metabolism of lactose by lactic acid bacteria. The production of lactic acids is strongly influenced by the amount of lactose and lactic acid bacteria contained in the milk. Wihansah et al. (2018) stated that lactose in the milk was also the main source of energy for the growth of lactic acid bacteria in fermented milk. Therefore, the result of lactose effect is the decreasing $\mathrm{pH}$ of kefir. According to Suharto et al. (2016), the activity of microorganisms converting milk lactose into lactic acid is followed by the lowered $\mathrm{pH}$. According to Purnomo \& Muslimin (2012), the decline $\mathrm{pH}$ is caused by the activities of Lactic Acid Bacteria in producing energy through the process of fermentation by breaking down the substrate to simpler compounds. Formation energy is targeted for cell formation. In addition to producing energy, the breaking down of lactose also produces lactic acid that eventually decreases $\mathrm{pH}$ value.

In the present study, the $\mathrm{pH}$ values of goat-milk kefir were lower compared to those reported by Purnomo \& Muslimin (2012) in the previous observation in goatmilk kefir (4.36-6.17) with 18 hours incubation time and the percentages of kefir grain of $3 \%, 5 \%$, and $7 \%$. The research of Hasan et al. (2014) showed that kefir produced with the addition of 3.5\% kefir grains for 24 hours incubation had $\mathrm{pH}=4.37$. Yusriyah \& Agustini (2014) revealed that with the addition $3 \%$ of kefir grain incubated for 24 hours produced goat-milk kefir with the $\mathrm{pH}=5.22$.

\section{Percentage of Lactic Acid in Goat-Milk Kefir}

In the present study, the percentage of lactic acid increases with the increased percentage of kefir grains supplementation. The percentage of lactic acid value is lower than that recommended by Codex Alimentarius Standard (Codex Stan 243-2003) i.e., at least 0.6\%. The lower percentage of lactic acid found in the present experiment is caused by the shorter incubation time i.e., 12 hours. The lactic acid bacteria in the medium will continue to grow by reforming the nutrient components. The final result of the lactic acid bacteria activities is lactic acid. Therefore, the longer the incubation period the higher the number of lactic acid produced. The lactic acid percentage of goat-milk kefir produced in the preset experiment was lower than that obtained by Hasan et al. (2014) yielding kefir with an acid level of $0.76 \%$ with the addition of $3.5 \%$ kefir grains. The higher percentage of lactic acid was inversely proportional to the decreased $\mathrm{pH}$ value of kefir. The lower $\mathrm{pH}$ value in kefir generates a higher percentage of lactic acid. This is due to the decreasing $\mathrm{pH}$ value caused by the increased number of lactic acids produced from the conversion of lactose into lactic acid. Lengkey \& Balia (2014) suggested that the best kefir could be produced by the addition of $10 \%$ kefir grain with 16 hours incubation period and the acidity of $1.476 \%$.

\section{Ethanol Levels of Goat-Milk Kefir}

The resulting ethanol content influences the taste of kefir produced. Chen et al. (2005) found an ethanol content of $1.18 \mathrm{~g} / \mathrm{L}$ in goat-milk kefir produced with the incubation period of 20 h. Purnomo \& Muslimin (2012) showed that the best goat-milk kefir was produced by the addition of $7 \%$ kefir grain of Indonesia incubated at room temperature for 24 hours with ethanol content of $0.92 \%$. Chen et al. (2005) produced kefir with $0.91 \%$ ethanol content by using 7\% kefir grains (w/v) with 24 hours of fermentation time. In addition, Hasan et al. 
(2014) found the ethanol content of goat-milk kefir by $0.917 \%$. These results differ from those reported by Yusriyah \& Agustini (2014), where the alcohol content of cow-milk kefir decreased with the increased concentration of kefir grain added as a result of the high total acid content produced by Lactobacillus bulgaricus that eventually causes the inhibition of growth of Candida in the kefir. The manufacturing method and culture type according to Codex Alimentarius Standard (Codex Stan 243-2003) reported by Pogačić et al. (2013) stating that a typical microbial population of kefir must contain Lb. kefiri as well as species Leuconostoc, Lactococcus, and Acetobacter (prepared from kefir grains) and yeast which fermented lactose (Kluyveromyces marxianus) as well as yeasts which do not ferment lactose (Saccharomyces cerevisiae and Saccharomyces exigous) when kefir grains are used for the culture. The total number of specified microorganisms from culture must be at least $10^{7} \mathrm{CFU} /$ $\mathrm{mL}$ and the number of yeasts is not under $10^{4} \mathrm{CFU} / \mathrm{mL}$.

\section{The Total Amount of Lactic Acid Bacteria}

The higher the percentage of kefir grain used resulted in the higher total of lactic acid bacteria in goat-milk kefir. Total amount of lactic acid bacteria for the addition of kefir grain at the levels of $2 \%, 4 \%$, and $6 \%$ were $1.64 \times 10^{7}, 1.71 \times 10^{7}$, and $1.76 \times 10^{7} \mathrm{CFU} / \mathrm{mL}$, respectively. The activity of lactic acid bacteria during incubation for 12-hours showed that the higher level of kefir grain increased the total number of lactic acid bacteria. It reveals that the addition of high kefir grains up to $6 \%$ shows the adaptation phase. In addition, the adaptation phase is faster compared to the number of lactic acid bacteria obtained and influence in the next phase such as the initial growth phase until the death phase. The growth activity of Lactic Acid Bacteria at 12 hours incubation shows the optimal growth phase and is likely to experience the increased growth to the logarithmic growth. Lactic acid bacteria have effects on the characteristics of goat-milk kefir produced. Indonesian National Standar 7552 in 2009 states that the number of colonies in fermented milk is $1 \times 10^{6}(6 \mathrm{log} \mathrm{CFU} / \mathrm{g})$. Codex Alimentarius Standar (Codex Stan 243-2003) states that the minimal amount total of microorganism from fermented milk is $10^{6} \mathrm{CFU} / \mathrm{g}$ and specifically on kefir the number of colonies minimal $10^{7} \mathrm{CFU} / \mathrm{g}$. Witthuhn et al. (2005) state that the counts of lactic acid bacteria are 8 $\log \mathrm{CFU} / \mathrm{mL}, 7.2 \log \mathrm{CFU} / \mathrm{mL}$, and $1.2 \times 10^{7} \mathrm{CFU} / \mathrm{mL}$. Witthuhn et al. (2004) reported that LAB and yeast levels present in kefir grains were $6.4 \times 10^{4}$ to $8.5 \times 10^{8}$ and $1.5 \times 10^{5}$ to $3.7 \times 10^{8} \mathrm{CFU} / \mathrm{mL}$, respectively. The results obtained are higher than the Indonesian National Standard and in accordance with the Standard Codex Alimentarus standard. These results are related to the incubation time of 12 hours that is the initial of logarithmic phase and likely to increase.

\section{The Weight Gain of Kefir Grains}

The highest weight gain of kefir grain is $13.84 \%$ found with the addition of $2 \%$ kefir grain with goat milk, while the lowest weight gain is $8.96 \%$ found with the addition of $6 \%$ kefir grain with goat milk. From these results, it can be seen that the use of higher percentage of kefir grains produces the lower weight gain of kefir grains. This negative relation is related to the condition that the high level of kefir grain causes the more acidic conditions. Therefore, the activity of lactic acid bacteria is inhibited. According by Lengkey et al. (2013), the weight gain of kefir grain decreases with the increasing levels of kefir grain i.e., at the levels of kefir grain $5 \%, 10 \%, 15 \%, 20 \%$, and $25 \%$ produced the the weight gains of kefir grain by 1,$4750 ; 3,190 ; 2,450 ; 2,270$; and 2,055, respectively. However, the highest weight gain of kefir grain is found in the supplementation of kefir grains at the level of $10 \%$. According to Lengkey (2002), the weight gain of kefir grain is strongly influenced by the content of lactose in the milk. Low lactose content will cause a low weight gain of kefir grain. The results obtained by Sulmiyati et al. $\left(2018^{\mathrm{b}}\right)$ show that supplementation of goat milk with kefir grain at the level of $2 \%$ incubated for 24 hours resulted in $26.61 \pm 4.7$ that is higher than the weight gain of cow-milk kefir (22.36 \pm 12.81$)$. Lengkey et al. (2013) several factors can inhibit or stimulate the growth of the starter in kefir production.

\section{Sensory Quality}

Goat milk kefir produced by kefir grains has no effect on the color of kefir produced. It shows that the process of kefir production does not produce materials that changes the color of goat-milk kefir produced. However, the level of kefir grain added into the media significantly influences the taste, smell, and has implications in the level of preference to the goat-milk kefir produced. The results suggested that the higher level of kefir grain gives the more acidic flavor of goat-milk kefir, but the panelists are still tolerate a more acidic flavor at the level of $4 \%$ kefir grain supplementaton. The taste of goatmilk kefir produced will have an impact on preference, which shows that the higher level of kefir grain affects the lower the level of preference. It indicates that the average panelists like kefir having a not too acid taste. The highest preference level was given to goat-milk kefir produced with the supplementation of kefir grain with a level of $2 \%$. Purbasari et al. (2013) revealed that the higher the concentration of kefir seeds increased the smell of goat-milk kefir. Wszolek et al. (2001) suggested that the sensory character of fermented milk products like kefir was mainly influenced by the type of milk, starter culture, and storage period. Physicochemical characteristics indirectly influence the organoleptic characteristics of goat-milk kefir. According to Paseephol \& Sherkat (2009) and Astawan et al. (2012), the reduction of $\mathrm{pH}$ value enhanced the sour and unique flavor of yoghurt.

\section{CONCLUSION}

Characteristics of goat-milk kefir have $\mathrm{pH}$ value of 5.40 , lactic acid $0.14 \%$, and ethanol content of $0.69 \%$. The weight gain of kefir grain was $7.21 \%$ and the total of lactic acid bacteria was $1.64 \times 10^{7} \mathrm{CFU} / \mathrm{mL}$. Sensory quality 
had 4.00 of color scale (white); 3.50 of smell scale (kefir scent), 4.90 of taste scale (not acid), and 3.5 of preference scale (like). The best goat-milk kefir can be produced by the addition of $2 \%$ kefir grain based on physicochemical, microbiological, and sensory characteristics.

\section{CONFLICT OF INTEREST}

Authors clarify that there is no conflict of interest with any financial, personal, or other relationships with other people or organization related to the material discussed in the manuscript.

\section{ACKNOWLEDGEMENT}

The Research was supported by HIBAH DIKTI through the Inter-University Cooperation Research Scheme (PKPT) University of Sulawesi Barat and Hasanuddin University 2017-2018 (the contract number 044/UN55.C/LT.09/2018). Authors sincerely thank to all those who kindly helped for operating laboratory instruments and in writing process of our manuscript.

\section{REFERENCES}

Agustina, L., T. Setyawardani, \& T. Y. Astuti. 2013. Penggunaan starter biji kefir dengan konsentrasi yang berbeda pada susu sapi terhadap $\mathrm{pH}$ dan kadar asam laktat (The use of different concentration of kefir grains on cow's milk and its effect on $\mathrm{pH}$ and lactic acid level). Jurnal Ilmiah Peternakan 1:254-259.

Arslan, S. 2015. A Review: chemical, microbiological and nutrional characteristics of kefir. Cyta-Journal of Food 13:340345. https://doi.org/10.1080/19476337.2014.981588

Astawan, M., T. Wresdiyanti., Suliantarai., I. I. Arief, \& R. Septiawan. 2012. Production of synbiotic yogurt-like using indigenous Lactic Acid Bacteria as functional food. Med. Pet. 35:9-14. https://doi.org/10.5398/medpet.2012.35.1.9

Chen, M. J., J. R. Liu, C. W. Lin, \& Y. Y. Tzu. 2005. Study of the microbial and chemical properties of goat milk kefir produced by inoculation with Taiwanese kefir grains. AsianAustralas. J. Anim. Sci. 18:711-715. https://doi.org/10.5713/ ajas.2005.711

Codex Allimentarius. 2003. Codex Standard for Fermented Milk (Codex Stand 243-2003) CCNEA document (CA/NEA 13/7/6).

Gao, X. \& B. Li. 2016. Chemical and microbiological characteristics of kefir grains and their fermented dairy products: A review. Cogent Food Agric. 2:1272152. https://doi.org/10.1 080/23311932.2016.1272152

Garofalo, C., A. Osimani, V. Milanović, L. Aquilanti, F. De Filippis, G. Stellato, S. Di Maura, B. Turchetti, P. Buzzini, D. Ercolini, \& F. Clementi. 2015. Bacteria and yeast microbiota in milk kefir grains from different Italian regions. Food Microbiol. 49:123-133. https://doi.org/10.1016/j. fm.2015.01.017

Gulitz, A., J. Stadie, M. Wenning, M. A. Ehrmann, \& R. F. Vogel. 2011. The microbial diversity of water kefir. Int. J. Food Microbiol. 151: 284-288. https://doi.org/10.1016/j. ijfoodmicro.2011.09.016

Hassan, F. A. M., H. M. Abbas, A. M. Mona, A. E. Gawad, \& A. K. Enab. 2014. Goats dairy products as a potentially functional food. Life Science Journal 11:648-657.

Leite, A. M. O., B. Mayo, C. T. C. C. Rachid, R. S. Peixoto, J. T. Silva, V. M. F Paschoalin, \& S. Delgado. 2012. Assessment of the microbial diversity of Brazilian kefir grains by
PCRDGGE and pyrosequencing analysis. Food Microbiol. 31:215-221. https://doi.org/10.1016/j.fm.2012.03.011

Leite, A. M. O., D. C. A. Leite, E. M. Del Aguila, T. S. Alvares, R. S. Peixoto, M. A. L. Miguel, J. T. Silva, \& V. M. F. Paschoalin. 2013. Microbiological and chemical characteristics of Brazilian kefir during fermentation and storage processes. J. Dairy Sci. 96:4149-4159. https://doi. org/10.3168/jds.2012-6263

Lengkey, H. A. W. 2002. Pengaruh penggunaan bermacam susu terhadap kadar $\mathrm{pH}$ dan pertambahan berat butiran kefir. Jurnal Ilmu Ternak 2: 38-41.

Lengkey, H. A. W., J. A. Siwi, \& R. L. Balia. 2013. The effect of various starter dosages on kefir quality. Lucrări ŞtiinţificeSeria Zootehnie 59:113-116.

Lengkey, H. A. W. \& R. L. Balia. 2014. The effect of starter dosage and fermentation time on $\mathrm{pH}$ and Lactic acid production. Biotechnology in Animal Husbandry 30: 339-347. https://doi.org/10.2298/BAH1402339L

Miguel, M. G. D. C. P., P. G. Cardoso, K. T. MagalhãesGuedes, \& R. F. Schwan. 2011. Profile of microbial communities present in tibico (sugary kefir) grains from different Brazilian States. World J. Microbiol. Biotechnol. 27: 1875-1884. https://doi.org/10.1007/s11274-010-0646-6

Paseephol, T. \& F. Sherkat. 2009. Probiotic stability of yoghurts containing Jerusalem artichoke inulins during refrigerated storage. Journal of Functional Foods 1: 311-318. https://doi. org/10.1016/j.jff.2009.07.001

Pogačić, T., S. Šinko, S. Zamberlin, \& D. Samaržija. 2013. Microbiota of kefir grains. Mljekarstvo 63:3-14.

Purbasari, N., A. Hantoro-DR, \& S. Wasito. 2013. Pengaruh konsentrasi biji kefir dan waktu fermentasi terhadap viskositas dan penilaian organoleptik kefir susu kambing (The influence of the concentration of seeds kefir and time fermentation against viscosity and judgment organoleptic kefir milk of goat). Jurnal Ilmiah Peternakan 1:1021-1029.

Purnomo, H. \& L. D. Muslimin. 2012. Chemical characteristics of pasteurised goat milk and goat milk kefir prepared using a different amount of Indonesian kefir grains and incubation times. J. Inter. Food Research. 19:791-794.

Setyawardani, T., A. H. D. Rahardjo, M. Sulistyowati, \& S. Wasito. 2014. Physiochemical and organoleptic features of goat milk kefir made of different kefir grain concentration on controlled fermentation. Anim. Prod. 16:48-54.

Standar Nasional Indonesia (Indonesian National Standar). 2009. SNI Nomor 7552:2009 tentang Minuman Susu Fermentasi Berperisai.

Suharto, E. L. S., I. I. Arief, \& E. Taufik. 2016. Quality and antioxidant activity of yogurt supplemented with Roselle during cold storage. Med. Pet. 39:82-89. https://doi. org/10.5398/medpet.2016.39.2.82

Sulmiyati, N. S. Said, D. U. Fahrodi, R. Malaka, \& F. Maruddin. 2018a. The characteristics of lactic acid bacteria isolated from Indonesian commercial kefir grain. Malays. J. Microbiol. 14:632-639. https://dx.doi.org/10.21161/ mjm. 117317

Sulmiyati., N. S. Said, D. U. Fahrodi, R. Malaka, \& F. Maruddin. 2018b. Perbandingan kualitas fisiokimia kefir susu kambing dengan susu sapi (Comparison of physiochemical quality of goat milk kefir with cow milk kefir). Jurnal Veteriner 19: 263-268. https://doi.org/10.19087/ jveteriner.2018.19.2.263

Swanson, K. M. J., F. F. Busta, E. H. Peterson, \& M. Jonhson. 1992. Colony Count Methods. In: C. Vanderzant., D.F. Splittsoesser (Eds). Compendium of Methods for The Microbiology Examination of Foods. $3^{\text {rd }}$ edition. The APHA Technical Commite on Microbiology Methods for Foods.

Taş, T. K., F. Y. Ekinci, \& Z. B. Guzel-Seydim. 2012. Identification of microbial flora in kefir grains produced 
in Turkey using PCR. J. Dairy Tech. 65:126-131. https://doi. org/10.1111/idt.2011.65.issue-1

Vardjan, T., P. M. Lorbeg, I. Rogelj, \& A. Čanžek Majhenič. 2013. Characterization and stability of lactobacilli and yeast microbiota in kefir grains. J. Dairy Sci. 96:2729-2736. https://doi.org/10.3168/jds.2012-5829

Wang, S. Y., H. C. Chen, J. R. Liu, Y. C. Lin, \& M. J. Chen. 2008. Identification of yeasts and evaluation of their distribution in Taiwanese kefir and viili starters. J. Dairy Sci. 91:37983805. https://doi.org/10.3168/jds.2007-0468

Wihansah, R. R. S., I. I. Arief, \& I. Batubara. 2018. Anti-diabetic potency characteristics of probiotic goat-milk yogurt supplemented with roselle extract during cold storage. Trop. Anim. Sci. J. 41:191-199. https://doi.org/10.5398/ tasj.2018.41.3.191

Wszolek, M., A. Y. Tamime, D. D. Muir, \& M. N. I. Barclay. 2001. Properties of kefir made in Scotland and Poland using bovine, caprine and ovine milk with different starter culture. LWT-Food Science and Technology 34:251-261. https://doi.org/10.1006/fstl.2001.0773
Witthuhn, R. C., T.Schoeman, \& T. J. Britz. 2004. Isolation and characterization of the microbial population of different South African kefir grains. J. Dairy Tech. 57: 33-37. https:// doi.org/10.1111/j.1471-0307.2004.00126.x

Witthuhn, R.C., T. Schoeman, \& T.J. Britz.2005. Characterisation of the microbial population at different stages of kefir production and kefir grain mass cultivation. J. Dairy Sci. 15. 383-389. https://doi.org/10.1016/j.idairyj.2004.07.016

Yilmaz-Ersan, L. Y., T. Ozcan, A. K. Bayizit, \& S. Sahin. 2016. The antioxidative capacity of kefir produced from goat milk. Int. J. Chem. Eng. Appl. 1:22-26. https://doi. org/10.7763/IJCEA.2016.V7.535

Yulianti, C. H. 2014. Uji beda kadar alkohol pada tape beras, ketan hitam dan singkong. Jurnal Teknika 6:531-536.

Yusriyah, N. H, \& R. Agustini. 2014. Pengaruh waktu fermentasi dan konsentrasi bibit kefir terhadap mutu kefir susu sapi (The effect of fermentation and concentration of kefir grains of quality of cow's milk kefir). UNESA Journal of Chemistry 3:53-57.

Zhou, J., X. Liu, H. Jiang, \& M. Dong. 2009. Analysis of the microflora in Tibetan kefir grains using denaturing gradient gel electrophoresis. J. Food Micro. 26: 770-775. https://doi. org/10.1016/j.fm.2009.04.009 